RNA 27: 324-334 (2021)

\title{
Corrigendum: Ancient microRNA profiles of 14,300-yr-old canid samples confirm taxonomic origin and provide glimpses into tissue-specific gene regulation from the Pleistocene
}

BASTIAN FROMM, MARCEL TARBIER, OLIVER SMITH, EMILIO MÁRMOL-SÁNCHEZ, LOVE DALÉN, M. TOM P. GILBERT, and MARC R. FRIEDLÄNDER

In the above-mentioned article, an incorrect ORCID iD was associated with author "M. Tom P. Gilbert." The correct ORCID iD is "0000-0002-5805-7195." This information has been corrected in the article online. 

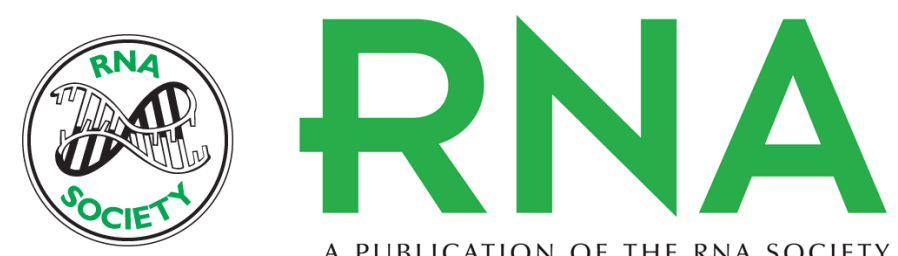

A PUBLICATION OF THE RNA SOCIETY

\section{Corrigendum: Ancient microRNA profiles of 14,300-yr-old canid samples confirm taxonomic origin and provide glimpses into tissue-specific gene regulation from the Pleistocene}

Bastian Fromm, Marcel Tarbier, Oliver Smith, et al.

RNA 2021 27: 1291

Related Content

Open Access

License

Email Alerting Service
Ancient microRNA profiles of 14,300 -yr-old canid samples confirm taxonomic origin and provide glimpses into tissue-specific gene regulation from the Pleistocene

Bastian Fromm, Marcel Tarbier, Oliver Smith, et al.

RNA March , 2021 27: 324-334

Freely available online through the RNA Open Access option.

Receive free email alerts when new articles cite this article - sign up in the box at the top right corner of the article or click here.

To subscribe to $R N A$ go to:

http://rnajournal.cshlp.org/subscriptions 